\author{
Board of Governors of the Federal Reserve System \\ International Finance Discussion Papers
}

Number 954

November 2008

Housing Market Risks in the United Kingdom

Robert F. Martin

NOTE: International Finance Discussion Papers are preliminary materials circulated to stimulate discussion and critical comment. References in publications to International Finance Discussion Papers (other than an acknowledgement that the writer has had access to unpublished material) should be cleared with the author or authors. Recent IFDPs are available on the Web at www.federalreserve.gov/pubs/ifdp/. 


\title{
Housing Market Risks in the United Kingdom
}

\author{
Robert F. Martin * \\ Federal Reserve Board
}

\begin{abstract}
House prices in the United Kingdom rose rapidly in recent years. The run-up, larger than any other in U.K. history, leveled off early last year. House prices are currently declining at rates faster than those seen in the early 1990's downturn. The housing downturn, however, is far from complete. Using the price-rent ratio as a guide, house prices are likely to fall at least a further 30 percent before leveling off. Given the historic links between housing and real activity, the downturn is likely to be associated with very slow growth. Going forward, we recommend the price-rent ratio as the appropriate measure of housing valuation.
\end{abstract}

JEL classification: E21, E22, R21

Keywords: Rent price ratio, house price, measurement.

*The views in this paper are solely the responsibility of the author and should not be interpreted as reflecting the views of the Board of Governors of the Federal Reserve System or of any other person associated with the Federal Reserve System.

Contact: robert.f.martin@frb.gov 


\section{Table of Contents}

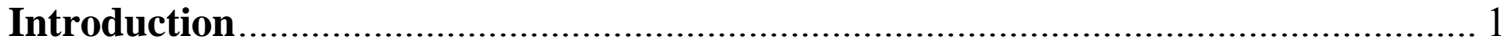

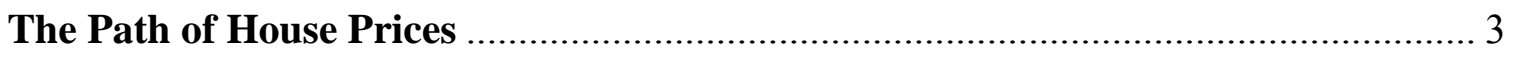

Figure 1a: House Prices: Level ........................................................................... 3

Figure 1b: House Prices: Growth Rates................................................................... 3

The Price-Rent Ratio: Theoretical Foundations .................................................... 4

The Mortgage Interest Rate as the Stochastic Discount Factor ............................. 8

Figure 2: Mortgage Interest Rates...................................................................... 8

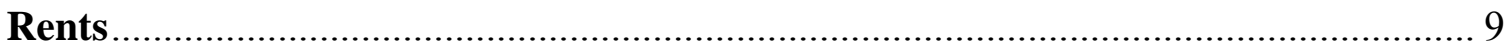

Figure 3: The Growth Rate of Rents.................................................................... 9

The Price-Rent Ratio: An Indicator of House Prices ........................................... 9

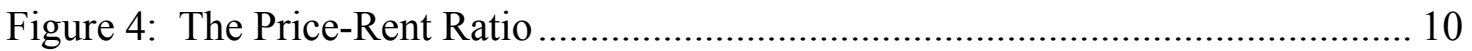

The Likely Path of Near-Term House Prices ......................................................... 11

Table 1: Annual Average House Price Appreciation to "Correct" Price-Rent Ratio .. 12

Table 2: Total Fall in House Prices over Adjustment Period .................................... 12

Mortgage-Market Innovation: An Extra Risk in the United Kingdom ................... 13

Macroeconomic Implications of a House Price Decline .......................................... 13

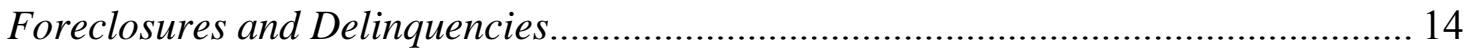

Table 3: The Relationship Between House Prices and Foreclosures........................ 14

Figure 5: Foreclosures in the United Kingdom...................................................... 15

Speculative Risk in the United Kingdom? ................................................................. 16

Figure 6: Delinquency Rates on Buy-to-Let Mortgages........................................ 16

Consumption ...................................................................................................... 16

Figure 7: Consumption Growth and House Price Appreciation ........................... 17

Residential Investment ......................................................................................... 18

Figure 8: Residential Investment as a Share of GDP........................................... 18

Figure 9: Contribution of Residential Investment to GDP Growth ........................ 19

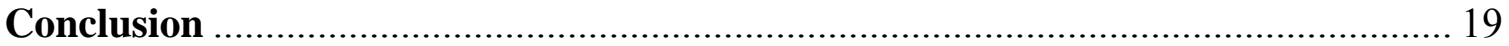

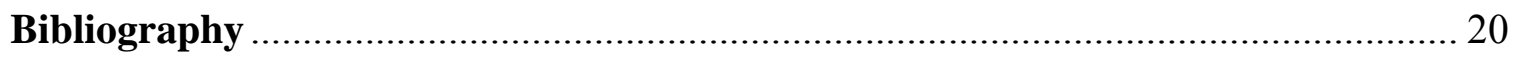




\section{Introduction}

House prices in the United Kingdom rose rapidly in recent years. As in the United States, house price appreciation in the United Kingdom was supported by solid economic fundamentals, including solid income growth, falling interest rates, and above-average population growth. Also, because most households borrow to finance house purchases, financial innovation may have contributed to higher house prices as larger pools of assets became available to purchase property.

Policy makers and economists, however, remain uncertain over the extent to which these fundamentals on their own supported the increase, as a number of studies found that traditional econometric models were unable to fully explain the run-up. For example, the OECD in a 2005 report cited overvaluation in the U.K. housing market as early as 2003. The IMF produced a series of reports from 2003 to 2008 that came to similar conclusions. At the same time, other academic studies disputed the findings. In particular, Cameron et al (2006) and Martin (2005), using very different models, found the level of U.K. house prices consistent with fundamentals.

Lending to non-traditional borrowers (known as the subprime borrowers in the United States) has further confounded the issue of valuation. Over the past ten years, financial innovation, mainly in the form of improved credit scoring and mortgage securitization, made mortgages available to a large group of households that had been previously excluded. These innovations originated in the United States but rapidly spread to other industrial countries, especially the United Kingdom. The increase in mortgage lending likely had a substantial effect on the value of housing. But, even in the United States where the difference between subprime and prime borrowers is relatively clear, the exact impact of subprime lending is not known.

Unfortunately, whether or not the run-up was fully justified or a bubble, many of the factors that supported rapid house price appreciation are now likely to contribute to a housing market slump. GDP growth in the United Kingdom has slowed and is forecast to slow further in the near term (Bank of England (2008)). Mortgage interest rates are well above their ten-year average and above-target inflation may prevent the Bank of England from reducing rates for some time. Population growth is slowing as the United Kingdom continues to age and as immigration has stabilized.

In addition, the collapse of the subprime market in the United States as well as in the United Kingdom is also likely to play a role in the decline. Mortgage securitization has slowed sharply since the onset of the subprime crisis in the United States and subprime issuance in the United Kingdom is almost non-existent at present. Investors are rethinking the value of subprime assets and this market is unlikely to reemerge anytime soon. There are risks that the pull back in lending could reduce funds to traditional borrowers. 
In this paper, we use a simple, theory-based, measure of housing valuation, the price-rent ratio $^{1}$, to predict the fall in prices needed to restore stability to the housing market in the United Kingdom. Using this summary measure eliminates the need to take a stand on the exact effect of different fundamental factors. We only need to take a view on the longterm prospects for the level of real interest rates and the growth rate of real rents. Going forward, we believe policy makers should use this indicator to judge the current state of the housing market.

The usefulness of the price-rent ratio to predict over- or under-valuation in house prices has been debated. Some authors believe this ratio omits the important factors driving house prices (Cameron (2006)). While others (IMF (2003)) lump the price-rent ratio in with a number of other macro ratios, with no clear guidance on which ratios are economically meaningful. Therefore, before using the price-rent ratio as a benchmark for housing, we derive the price-rent ratio from standard asset pricing equations. This derivation permits us to link the price-rent ratio to its underlying determinants and to state explicitly the reasons we believe the price-rent is likely to return to a value closer to its long-run average.

The price-rent ratio indicates that house prices are likely to fall much further before stabilizing. In our base-line (benign) scenario, house prices are predicted to fall 4.3 percent annually over the next 7 years for a total additional decline near 30 percent. Faster price adjustment requires larger house price falls. This adjustment is somewhat larger than the price adjustment that occurred in the early 1990s. However, we believe that these estimates may very well prove optimistic as the impact of the subprimeinduced credit turmoil is likely to be substantial.

House price declines are also typically associated with poor macroeconomic outcomes, as foreclosures rise, consumption growth slows, and residential investment falls. Further, because of the likely effect on output, standard Taylor-rule arguments imply that the Bank of England should respond to falling house prices by reducing policy rates.

However, at the current time, inflation in the United Kingdom is well above the Bank of England's target-four percent rather than the two-percent target. This high level of inflation may constrain the Bank's interest setting policy. In addition, Ahearne et al (2005) show that, across countries and across time periods, inflation tends to rise during times when house prices are falling from their peak, with the peak in inflation occurring 4 to 6 quarters after the peak in house prices.

\footnotetext{
${ }^{1}$ The price-rent ratio may be thought of as the equivalent of the price-earnings ratio for stocks and is considered a good measure of the real valuation of housing (see Davis et al (2008)).
} 


\section{The Path of House Prices}

The charts shown in figure $1 \mathrm{a}$ and $1 \mathrm{~b}$ show the path of U.K. house prices since the early 1980s. Figure 1a shows an index of nominal house prices and figure $1 \mathrm{~b}$ shows the twelve-month change of house prices over the same period.

Figure 1a: House Prices: Level

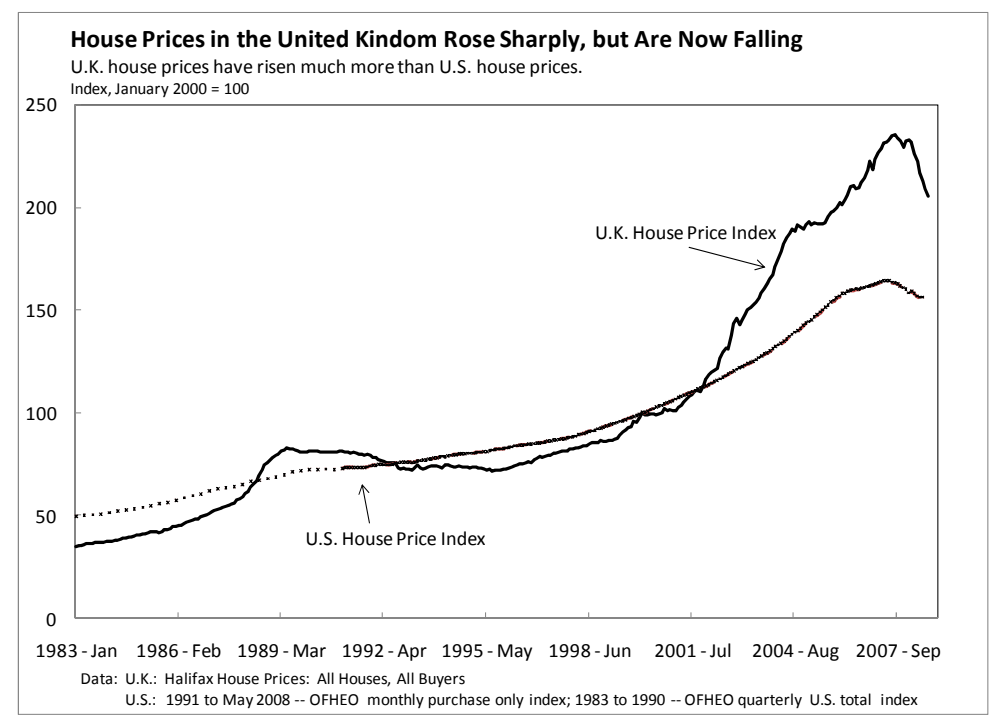

Figure 1b: House Prices: Growth Rates

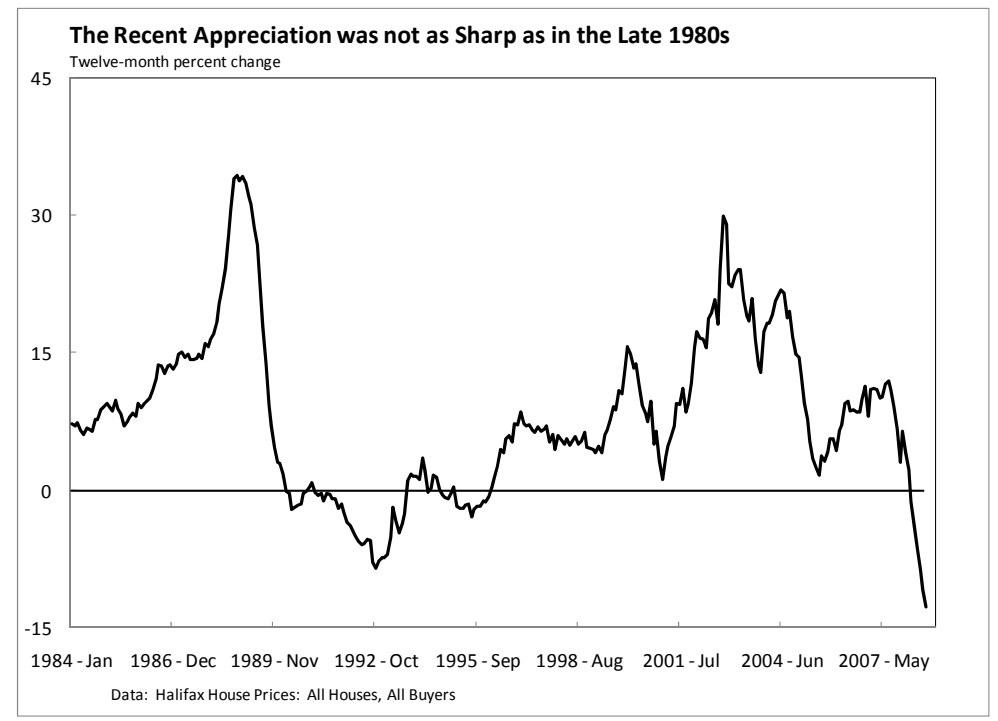

After remaining more or less unchanged throughout the 1990s, the level of house prices has more than doubled in the United Kingdom since the beginning of 2000. In contrast, the recent increase in house prices in the United States has been relatively mild. This 
trend is similar to past episodes. In the late 1980 s and early $1990 \mathrm{~s}$, U.S. house prices rose much less and also managed to avoid the outright decline in prices experienced in the United Kingdom.

In the United Kingdom, house prices reached their nadir in mid-1996. Following the trough, house prices increased mildly until around 1999 when the first in a long series of double-digit gains occurred. The run-up was particularly acute between 2002 and 2004. Figure $1 \mathrm{~b}$ shows that, over these two years, house price inflation remained in the upper teens and twenties, brushing against 30 percent in October 2002.

The most striking difference between the most recent house price boom and the one that occurred in the late 1980s is the number of years the expansion lasted. In the late 1980s, double-digit house price inflation was contained to essentially a three-year period, although from July 1988 to June 1989 house price inflation exceeded 25 percent. The most recent episode lasted close to ten years, with only two interim slow growth years.

House prices reached a peak in early 2007, and between May 2007 and June 2008, house prices fell close to 10 percent, a rate of decline near the maximum fall experienced during the early 1990s downturn. However, house prices in that earlier episode gradually accelerated to that pace of decline. Unless adjustment is occurring faster in this episode than in the past, we may have a long way to go before the housing market stabilizes.

Of course, house prices alone are not a useful measure of over- or under-valuation. At the very least, we expect house prices to increase at the rate of inflation over long periods of time. In addition, the relative price of housing may also increase. Housing embodies land and, to a greater or lesser extent, land is in fixed supply. Population growth and income growth may both translate into a shift in house prices. For these reasons, the deflator must be chosen with care. ${ }^{2}$ In the next section, we show that deflating house prices by rents is correct in an asset pricing sense. We also show that the price-rent ratio is stationary on a balanced growth path.

\section{The Price-Rent Ratio: Theoretical Foundations}

Some authors directly dispute the usefulness of the price-rent ratio as a measure of housing valuation. For example, Cameron et al (2006) state that "[the price-rent ratio is] not very informative about the presence or absence of bubbles, because [it] ignore[s] a range of other important factors, including demographic and population changes, housebuilding, credit conditions, and other asset prices."

In response to this line of reasoning, we derive the price-rent ratio from a basic model of housing demand. We show that the price-rent ratio depends solely on the expected future

\footnotetext{
${ }^{2}$ For example, with land in fixed supply the ratio of house prices to overall inflation (real house prices) and the ratio of house prices to wages would both trend and there is no reason to expect a linear trend.
} 
growth rate of rents and the future expected evolution of the stochastic discount factor. Therefore, in the model, the price-rent ratio responds to changes in underlying economic fundamentals that affect either consumption growth or the discount rate. Therefore, while the factors listed by Cameron et al are undoubtedly correct, the price-rent ratio serves admirably as a simple summary variable of all of them. ${ }^{3}$

The economy consists of a large number of identical households who receive per-period utility from consumption of non-housing goods, $c_{t}$, and consumption of a housing good, $\mathrm{h}_{\mathrm{t}}$. The housing good is a composite of owner-occupied housing and rental housing. Each household chooses sequences of consumption, rental housing, and a stock of owneroccupied housing to solve the following program:

$$
\begin{gathered}
\max _{c, h, H} \sum_{t=0}^{\infty} \beta^{t} U\left(c_{t}, h_{t}\right) \\
\text { subject to } \\
h_{t}=\delta H_{t}+h_{t}^{R} \\
c_{t}+\rho_{t} h_{t}^{R}+P_{t} H_{t}+B_{t}=w_{t}+P_{t} H_{t-1}+r_{t-1} B_{t-1}
\end{gathered}
$$

Rental housing is denoted, $h_{t}^{R}$, and units of rental housing are chosen such that $h_{t}^{R}$ represents the flow consumption of rental housing. Because households purchase the full stock of owned housing, the stock must be converted to a flow value. The parameter $\delta$ makes this adjustment and maps the stock of owner-occupied housing, $\mathrm{H}$, into flow housing consumption.

Rent in the current period is denoted by $\rho$. The price of housing is denoted by $\mathrm{P}$ and the one-period real interest rate is denoted by $r$. The household also works and receives labor income, w. All variables are measured in per capita terms and all prices are real (because the model is real).

The model is unconstrained and households may borrow or lend as much as they desire at interest rate $\mathrm{r}$. Any constraints or additional costs are assumed to be incorporated into the interest rate. For example, a household that faces a borrowing constraint is assumed to face a prohibitive interest rate at that point.

\footnotetext{
${ }^{3}$ The model we derive is also given in full form in Davis and Martin (2008) and the model underlies the analysis in Cambell et al (2006).
} 
The first-order conditions for consumption, bonds, rental housing, and owner-occupied housing are as follows:

$$
\begin{aligned}
& c: U_{c}=\lambda_{t} \\
& h: U_{h}=\rho_{t} \lambda_{t} \\
& H: \delta U_{h}=-P_{t} \lambda_{t}+E P_{t+1} \lambda_{t+1} \\
& B: \lambda_{t}=r_{t} E \lambda_{t+1}
\end{aligned}
$$

The Lagrange multiplier on the budget constraint is denoted by $\lambda$. This set of first-order conditions implies that current period rents are pinned down by the ratio of housing to non-housing marginal utility and that the current period real interest rate is equal to the inverse of the stochastic discount factor, $E \lambda_{t+1} / \lambda_{t}$. This solution is standard.

Combining the four first-order conditions into a single equation, we arrive at a simple and standard pricing equation for owner-occupied housing.

$$
P_{t}=\delta \rho_{t}+E \frac{1}{r_{t}} P_{t+1}
$$

The price of owner-occupied housing is equal to the rental value of housing (adjusted for its flow value) plus the discounted value of selling the property tomorrow. Solving forward, the price of owner-occupied housing is equal to the present value of future rents.

$$
P_{t}=\delta \sum_{s=0}^{\infty} E \rho_{t+s} \frac{1}{\prod_{j=1}^{s} r_{t+j}}
$$

We derive the price-rent ratio by dividing both sides of the pricing equation by time $\mathrm{t}$ rents.

$$
\frac{P_{t}}{\rho_{t}}=\delta \sum_{s=0}^{\infty} E \frac{\rho_{t+s}}{\rho_{t}} \frac{1}{\prod_{j=1}^{s} r_{t+j}}
$$

The first term inside the expectation is the growth rate of rents between period $t$ and $t+s$ while the second term is the period $t$ to $t+s$ discount rate. The expectation is conditioned on information in time $t$.

The last equation shows that the price-rent ratio depends solely on the stochastic discount factor and the growth rate of rents (our initial claim). All other variables move the pricerent ratio only through their impact on these two variables.

We take each example given by Cameron et al in turn to see how they fit in the model.

1. Demographic and/or population changes - these determine the per capita values of $\mathrm{c}$ and $\mathrm{h}$. Holding all else constant, population increases reduce per capita 
consumption. Predictable changes in either impact both the discount rate and the expected future growth of rents. The dominant effect depends on the utility function chosen (see Martin (2005)).

2. House-building - changes the supply of both rental and owner-occupied housing and lowers the marginal utility of housing, $\mathrm{U}_{\mathrm{h}}$. Only variations in the path matter. Constant changes in supply (such as building today), change both the denominator and the numerator of the rent growth term, $\rho_{\mathrm{t}+\mathrm{s}} / \rho_{\mathrm{t}}$.

3. Credit conditions - Credit conditions are not explicitly incorporated into the above model. Therefore, we must interpret $r$ loosely as the total cost of borrowing (recall if a household is short in mortgage bonds, the correct interest rate is the after tax mortgage rate). Further, we must think of credit constraints as changes in $\mathrm{r}$. Given these loose assumptions, we see that long-run level of the price-rent ratio is shifted by permanent changes in the discount rate. This permanent change can result from lower interest rates or easier credit. ${ }^{4}$

4. Other asset prices - the model only explicitly considers the one-period interest rates; however, all of the equations remain valid if this interest rate is replaced by the rate of return on a portfolio of any other set of assets, including stocks and property owned for rental purposes.

While the price-rent ratio does not have to stay near its long-run average, historically it has tended to. Following large deviations (either up or down), the ratio has tended to its trend value. For example, Gallin (2004) shows that, for the United States, the price-rent ratio reverts to its long-run trend. ${ }^{5}$ Further, he shows that house prices tend to do most of the adjusting. While we do not have equivalent studies for other countries, we expect this general tendency to hold in most industrial countries. ${ }^{6}$

In our analysis of the future path of house prices, we will work directly with the pricerent ratio rather than with rents and discount rates directly. Cambell et al (2006) study the properties of the price-rent ratio for the United States by creating forecasts of future rents and interest rates. While this exercise is useful, they attribute most of the fluctuation in the price-rent ratio to changes in the risk premium. Clearly, this risk premium is a combination of actual premia and errors in their forecasts.

In this paper, we take a simpler stance and work directly with the price-rent ratio. Our implicit assumption is that future rent growth is constant and that the level of real interest

\footnotetext{
${ }^{4}$ For example, Davis et al. (2008) argue that a change in U.S. mortgage regulations in the early 1980s may have led to a permanent shift in the price-rent ratio. This is also essentially the argument of Cameron et al (2006) that a bubble did not exist in the U.K. housing market because the change in prices was justified by a change in credit availability (and many other factors).

${ }^{5}$ Gallin (2004) finds an increasing time trend. Davis et al. (2008) argue for zero trend following a one-time break in the series in the early 1980s.

${ }^{6}$ A sufficient (but not necessary) condition for the price-rent ratio to be stationary is for both interest rates and the growth rate of rents to be stationary.
} 
rates does not change. In the next two sections, we show the historical properties of both rents and interest rates and will use these properties to guide our analysis of the price-rent ratio in the following section.

\section{The Mortgage Interest Rate as the Stochastic Discount Factor}

As our discussion of the impact of interest rates is informal, we use nominal interest rates throughout the paper. Over the period of interest, the fluctuations in inflation are small and the real interest rate may be thought of as a level shift of between 2 and 3 percentage points. Inflation was consistently below the 3 percent upper band of the Bank of England's inflation target. Only in the most recent months has inflation shown any tendency to exceed this level. Inflation rose to nearly 4 percent at the end of the second quarter of 2008 and is expected by the Bank of England to rise further before subsiding. However, the underlying rate of inflation, as measured by inflation excluding food and energy, has remained stable and over the medium term inflation is likely to be much lower.

We choose the mortgage interest rate as the relevant proxy for the discount rate. Figure 2 shows the path of mortgage interest rates in the United Kingdom between 1995 and 2008. In 1995, interest rates were nearly 10 percent. Over the subsequent eight years, mortgage interest rates dropped around five percentage points, reaching a low of around 4.5 percent at the end of 2003. One school of thought held that high long-term interest rates were a thing of the past; central banks had defeated inflation and has solid control over the real economy.

\section{Figure 2: Mortgage Interest Rates}

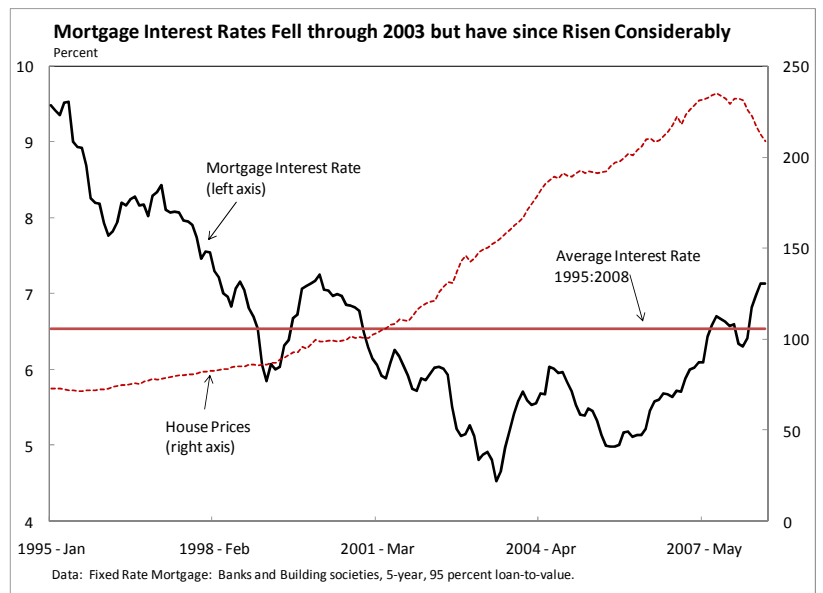

Since late 2005, however, mortgage interest rates have risen considerably. Recently, interest rates breached their 1995 to 2008 average level and are quite similar to their 2000 levels; the year house price appreciation seemed to accelerate in the United Kingdom. 
The higher level of the interest rate implies a substantially reduced level of support to house prices. If interest rates were the sole factor underlying the run-up, we would expect the level of house prices to return toward their 2000 level.

Interest rates are no more supportive of the price-rent ratio now than they were in early 2000. Holding expected rent growth constant, the price-rent ratio should then return to its 2000 level. Market prices indicate that most traders believe policy rates will be on hold over the medium term. We do not believe change in the present value of the discount factor is driving the behavior of the price-rent ratio.

\section{Rents}

Figure 3 shows the time series of rent increases between 1988 and 2008. For the last 15 years of this data, rent inflation remained steady between 3 and 4 percent. The prominent exception is the 1 percent inflation during the economic slowdown in 2001 and 2002. In the late 1980s and very early 1990s, rent inflation was much higher, reaching a peak near 14 percent in 1991. Since that time, rent growth appears stable and we see nothing in the data to push us toward believing market expectations of rent growth has changed. ${ }^{7}$ However, one reason we allow rent growth to change in the simulations below is the high rent growth observed in the early part of the sample.

Figure 3: The Growth Rate of Rents

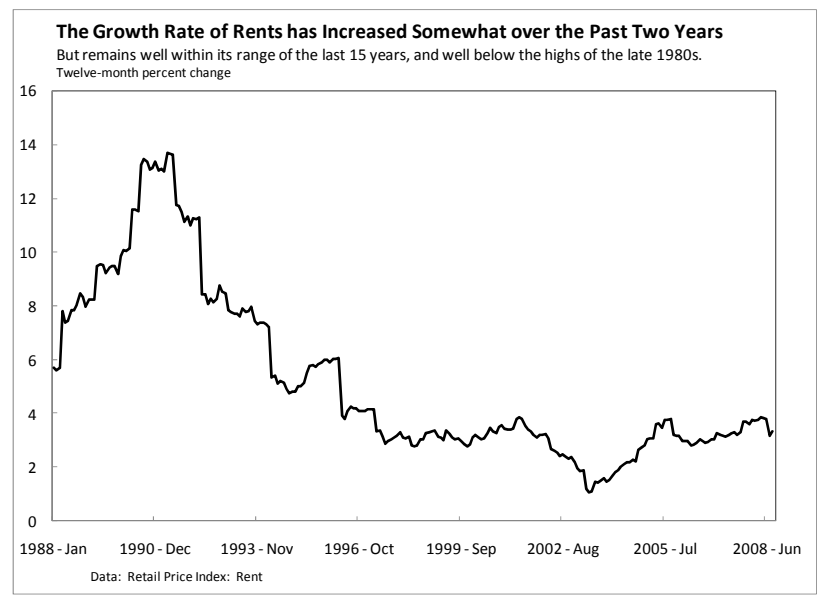

\section{The Price-Rent Ratio: An Indicator of House Prices}

Figure 4 shows the price-rent ratio for the United Kingdom and, for comparison, the price-rent ratio for the United States. ${ }^{8}$ Not surprisingly given the stability in rent growth,

\footnotetext{
${ }^{7}$ Regressions of rent growth on lagged rent growth indicate rapid reversion to mean growth of about 3 percent.

${ }^{8}$ The ratio for the United States is taken from Davis et al. (2008) and is calculated using census data on the level of both house prices and housing rents. The ratio for the United Kingdom is calculated using the level
} 
the price-rent ratio has followed the path of house prices in recent years. And, like house prices, the price-rent ratio in both countries is well above its range.

Over the period shown, the price-rent ratio for both the United Kingdom and the United States appear to have a solid upward trend. While we do not have the data to extend the U.K. series back further (we do not have rent data), the U.S. series goes back to 1964 . Over the full time period, the U.S. series appears stationary until around 1996. We do not know how the U.K. series would appear in a longer sample, but we assume it would have a similar pattern to that of the United States.

The apparent trend in the price-rent ratio likely owes to the fall in mortgage interest rates over the period shown. As was discussed above, global interest rates fell through much of the 1990s. Effective mortgage interest rates likely fell even faster as the overhead costs of obtaining mortgages was steadily reduced during this period (Tsatsaronis and Zhu (2004)). Interest rates are now returning to, at least, their levels of the late 1990s and the costs of mortgage finance are likely to rise as lenders take more care in offering credit.

The price-rent ratio for the United Kingdom has more than doubled since 1996. The fastest increases in the series occurred between the first quarter of 2002 and the third quarter of 2004. This was a period where rent growth was slow on average and where house prices grew consistently in the double digits.

\section{Figure 4: The Price-Rent Ratio}

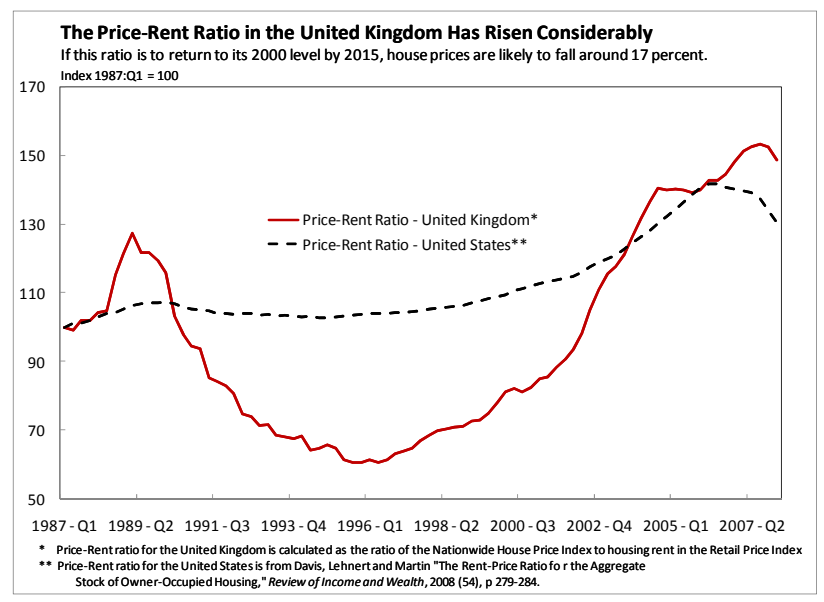

The recent large decline in house prices has only begun to shift the price-rent ratio down. Clearly, if this series is to return to its long-run average, a larger and more sustained

of house prices from the Nationwide quarterly house prices series - a quality adjusted, repeat transaction level. Unfortunately, in the United Kingdom rents in pounds are not readily available. Therefore, we compute an index of the price-rent ratio using the rental index from the Retail Price Index. 
move in house prices must occur. In the next section, we attempt to measure the needed move.

\section{The Likely Path of Near-Term House Prices}

In this section, ignoring any impact of changing interest rates ${ }^{9}$, we conduct a simple arithmetic calculation to find the change in house prices necessary to return the price-rent ratio to some specified target. The change in the price-rent ratio can be written as follows:

$$
\Delta \log (\text { House Prices } / \text { Rents })=\Delta \log (\text { House Prices })-\Delta \log (\text { Rents })^{10}
$$

Then, given an assumption on the growth rate of rents ${ }^{11}$, we compute the annual average change in house prices needed to restore the price-rent ratio back to a target level in a specific amount of time.

The amount house prices have to fall to return the price-rent ratio to any target depends critically on how much the price-rent ratio has to adjust, the time period over which adjustment occurs, and the rate of rent inflation over the same period. Our baseline assumption is for the price-rent ratio to return to its 2000 level by 2015 . Using the year 2000 as a baseline level seems reasonable to us because this is the year when house prices accelerated most sharply and the interest rate contribution to the ratio was the same then as it is now (see footnote 9). The length of adjustment is more debatable. The last adjustment period lasted about seven years, although the rate of change was not constant over the time period. Hence, the year 2015 was chosen to match the time of adjustment in the previous episode.

Rent inflation is also a big question. Over the past several years, rents have increased at an annual rate of between 3 and 4 percent; however, following the last peak in house prices, rent growth accelerated, reaching a peak over 13 percent (12-month change) in April 1991. Average rent growth between 1990 and 1996 was 7.6 percent. Therefore, we choose to show results for 4 and 8 percent rent inflation.

\footnotetext{
${ }^{9}$ Using the techniques in Cambell et al. (2006) we find that the interest rate term is making nearly an identical contribution to the price-rent ratio in 2008 as it did in 2000.

${ }^{10}$ We use log changes to find the new level because our measures of both house prices and rents are indexes: $\log ($ House Prices / Rents $)=\log$ (Index factor for house prices / Index factor for rents $)+$ $\log$ (House Prices / Rents).

${ }^{11}$ We ignore the impact of higher rent growth on the long-term level of the price-rent ratio.
} 
Table 1: Annual Average House Price Appreciation to “Correct” Price-Rent Ratio

\begin{tabular}{|l|ccc|}
\hline & $\begin{array}{c}\text { Return to 2000 } \\
\text { Level by 2015 }\end{array}$ & $\begin{array}{c}\text { Return to 2000 } \\
\text { Level by 2010 }\end{array}$ & $\begin{array}{c}\text { Return to 1996 } \\
\text { Level by 2015 }\end{array}$ \\
\hline Rent Growth 4\% & $-4.1 \%$ & $-22.1 \%$ & $-8.3 \%$ \\
Rent Growth 8\% & $-0.4 \%$ & $-18.7 \%$ & $-4.5 \%$ \\
\hline
\end{tabular}

Table 1 gives our results. In the first column, we assume that the price-rent ratio returns to its 2000 value by the beginning of 2015. If rent growth is 4 percent per year (somewhat higher than its average growth rate over the past five years), house prices must fall 4.1 percent annually to bring the price-rent ratio back in line. That is, between the first quarter of 2008 and the first quarter of 2015, house prices would fall close to 30 percent. $^{12}$ If we double the rate of rent growth to 8 percent, house prices need only fall 0.4 percent per year.

In the second column, we assume a return to the 2000 level by 2010 . Under the same assumptions on rental growth, this requires a much faster rate of house price depreciation-22.1 percent with 4 percent rent growth and 19 percent with 8 percent rent growth. In this case, the difference in rent growth makes much less difference because the growth differential has less time to affect the average.

Table 2: Total Fall in House Prices over Adjustment Period ${ }^{13}$

\begin{tabular}{|l|ccc|}
\hline & $\begin{array}{c}\text { Return to 2000 } \\
\text { Level by 2015 }\end{array}$ & $\begin{array}{c}\text { Return to 2000 } \\
\text { Level by 2010 }\end{array}$ & $\begin{array}{c}\text { Return to 1996 } \\
\text { Level by 2015 }\end{array}$ \\
\hline Rent Growth 4\% & $30 \%$ & $39 \%$ & $50 \%$ \\
Rent Growth 8\% & $3.1 \%$ & $34 \%$ & $31 \%$ \\
\hline
\end{tabular}

The level to which the price-rent ratio is likely to correct is not known. As noted above, 2000 seems a reasonable assumption. However, other factors may push the price-rent ratio down even further. For example, mortgage securitization and the subprime market (discussed below) may have contributed to the boom. With these forces less active, house prices may have to fall even further. As a result, the price-rent ratio may move all the way back to its level of the mid-1990s - the level it reached in the last housing market bust. The final column of Table 1 gives the rate of house price appreciation to reach this level by the end of 2015 .

\footnotetext{
${ }^{12}$ These appreciation and deprecation rates are nominal. Real house prices declines would likely be considerably larger.

${ }^{13}$ The adjustment period is from the end of 2007 to the end of 2015.
} 
Table 2 shows the total fall in house prices under each scenario given in Table 1. Looking at the first row of the table, if the adjustment occurs over 7 years, house prices fall around 30 percent. If however, the adjustment occurs faster, even with the same growth rate of rents, house prices must fall almost 40 percent. This difference is particularly striking when the rent growth is high. The fall in house prices is, of course, particularly large if the price-rent index must return to its 1996 level. With rent growth of 4 percent, house prices must fall around 50 percent.

\section{Mortgage-Market Innovation: An Extra Risk in the United Kingdom}

Although the United Kingdom does not appear to have relied on mortgage securitization to the extent of the United States, mortgage securitization was important to several U.K. lenders ${ }^{14}$ and this market appears to have little if any volume between August 2007 and September 2008. This form of mortgage finance innovation likely contributed to easier credit standards, ${ }^{15}$ allowing more households to borrow. With this model no longer tenable, credit standards are likely to be stricter, putting downward pressure on house prices.

Contributing to the downside risks are subprime mortgages in the United Kingdom. Subprime mortgages are a relatively small portion of the mortgage market in the United Kingdom. According to press reports referencing Standard \& Poor's research, only about $£ 43$ billion subprime mortgages are represented in the mortgage-backed securities market - this (if true) represents about 3 percent of total mortgages outstanding. However, according to the same reports, about 25 percent of these mortgages are currently delinquent. ${ }^{16}$ If one-half of the subprime mortgages that are (allegedly) delinquent in the United Kingdom end up in foreclosure, they would by themselves push the overall foreclosure rate above its 1991 peak. In addition, these foreclosures will likely put downward pressure on house prices and contribute to rising foreclosures outside of the subprime market.

\section{Macroeconomic Implications of a House Price Decline}

House price declines, of course, have many well-documented macroeconomic feedbacks. Ahearne et al (2005) provide a thorough survey of the correlation between house price declines and other macroeconomic variables. This impending decline is likely to be

\footnotetext{
${ }^{14}$ Northern Rock is an excellent example. Northern Rock, the eight largest U.K. bank, transformed itself from a building society to a bank. Its portfolio was concentrated in mortgage and real-estate loans and it relied on the securitization market for funding. Its business model became untenable following the financial crisis in August 2007, and following a run on the bank, it was essentially nationalized. Given the need for extensive government intervention, this model of mortgage lending is likely to be substantially curtailed for the foreseeable future in the United Kingdom.

${ }^{15}$ This easing of credit is not necessarily an indicator of bad lending practices. To the extent that mortgage securitization diversifies risk, mortgage terms should be easier.

${ }^{16}$ This rate is similar to the delinquency rate on U.S. subprime mortgages.
} 
associated with poor macroeconomic outcomes, as foreclosures rise, consumption growth slows, and residential investment falls.

\section{Foreclosures and Delinquencies}

In this section, we focus on the relationship between house price declines and mortgage foreclosures. While many factors contribute to rising foreclosure rates-high interest rates, low or volatile employment rates - the rate of house price appreciation has long been considered one of the best predictors. ${ }^{17}$ And theoretical link between an owner's equity in his home and his probability of default is undisputed.

We find a tight relationship between house prices and foreclosure rates in the United Kingdom. We ran regressions of foreclosures on real house prices, employment, and short- and long-term interest rates. All variables except the interest rates are measured as log changes and various lag lengths of each variable are included. We also included lagged dependent variables in the regression.

Table 3: The Relationship Between House Prices and Foreclosures

\begin{tabular}{|c|cccc|}
\hline & Coefficient & Std Error & T-Stat & P-value \\
\hline Constant & -0.02 & 0.05 & -0.41 & 0.68 \\
House Prices & -1.47 & 0.58 & -2.50 & 0.01 \\
Lagged Foreclosure & 0.28 & 0.15 & 1.89 & 0.06 \\
\hline
\end{tabular}

Across all specifications, we found that a one percent fall in house prices is associated with between a one and two percent rise in possession rates. Table 2 gives results for a regression that includes two lags of each independent variable and one lag of foreclosures. The coefficient on house prices is statistically significant and these results are representative of our regression results.

\footnotetext{
${ }^{17}$ House price appreciation likely correlates well with foreclosure rates for two reasons. First, house price appreciation directly changes the owner's level of equity. Higher equity implies the home owner is less likely to benefit from defaulting on the mortgage. Second, housing is a long-lived durable consumption good. As a consumption good in locally fixed supply its value is directly related to the level of overall consumption. As a long-lived durable good, housing serves as an investment and hence capitalizes future consumption and income growth. Falling house prices: Bad economic times.
} 


\section{Figure 5: Foreclosures in the United Kingdom}

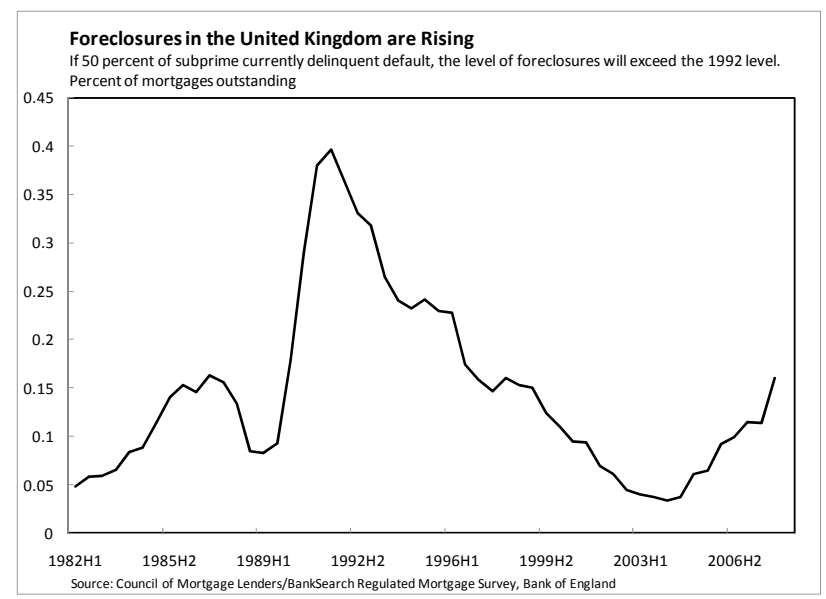

The response of foreclosures to house prices is remarkably stable across the early and late sample periods. The model fits reasonably well even through the spike in possessions in 1991 and the long and protracted decline in possessions thereafter (see figure 5).

Given our estimated elasticity and given the potential price declines highlighted in the previous section, foreclosure rates have the potential to increase anywhere from 40 to 80 percent (implied by row one of table 1). However, even if foreclosure rates were to double, the rate would remain below the very high level achieved in 1991.

That they would remain benign (compared with a really bad outcome) also highlights risks to this analysis. The price run-up prior to the previous housing-market bust in the United Kingdom was mild compared with the current episode. Although no two housing market busts are likely to play out exactly the same way, one might expect a more severe downturn following the more vigorous run-up. Also, between the second half of 2007 and the first half of 2008, house prices fell 10 percent at the same time as foreclosures rose 40 percent, although we would never expect regression results to perfectly predict such high frequency changes.

In addition to falling house prices, households in the United Kingdom are facing higher mortgage interest rates. All U.K. mortgages are variable rate mortgages by U.S. standards. Fixed-rate mortgages in the United Kingdom typically float after a period of 2 to 3 years. Therefore a household who obtained a fixed-rate mortgage in 2004 would most likely have seen their interest payments rise by the end of 2007, raising the probability of foreclosure in these households.

The direct implication of foreclosures on the housing market is not known. Intuitively, a large number of foreclosures adds to the supply of housing on the market and should put downward pressure on house prices. We believe this to be the case. Foreclosures have a negative effect on the bank balance sheets and may pose a risk to the banking system. 
And, to the extent that rising foreclosures are predictable, banks may be less willing to lend as the return on lending is lower when foreclosures are high. We conducted Granger causality tests and found no clear indication of causality; however, Calomiris et al (2008) using data for U.S. states found house price changes have a significant impact on foreclosure rates, but rising foreclosures have at most a weak influence on house prices.

\section{Speculative Risk in the United Kingdom?}

Buy-to-let (not owner occupied) mortgages have grown as a share of mortgages since they were first tracked in 1998. By the second half of 2007, the number of buy-to-let mortgages accounted for almost 9 percent of outstanding mortgages. During the housing boom, the rise in this number of this class of purchases may have been associated with increased speculation (purchases intended for resale only) in the U.K. housing market. If this is true, these mortgages may be more likely to stop performing as investors walk away from their losses. ${ }^{18}$ However, these mortgages have consistently outperformed aggregate mortgages in terms of foreclosure rates. Figure 6 shows serious delinquencies and foreclosures (all mortgages three or more months in arrears) for both the buy-to-let segment and for aggregate mortgages.

\section{Figure 6: Delinquency Rates on Buy-to-Let Mortgages}

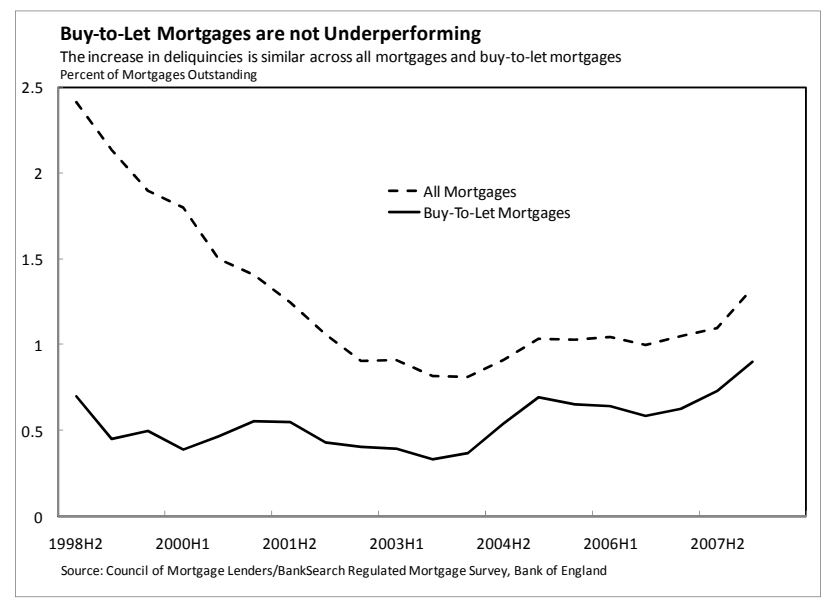

\section{Consumption}

Consumption growth and house price appreciation are highly correlated. The unconditional correlation between quarterly house price appreciation and quarterly real

\footnotetext{
${ }^{18}$ All mortgages are recourse in the United Kingdom. That is, in the event that a mortgagee stops making payments the lender can seek payment from their other assets and income. Nevertheless, not all lenders pursue borrowers as court cases raise the cost of foreclosure.
} 
consumption growth in the United Kingdom is 0.46 . This correlation increases to 0.62 if four-quarter growth rates are used. Four-quarter house price appreciation and fourquarter real consumption growth are shown in figure 7. Similar correlations are found in U.S. data and, in the United Kingdom, the correlation remains near its full sample level if we only look at the correlation in five-year windows.

\section{Figure 7: Consumption Growth and House Price Appreciation}

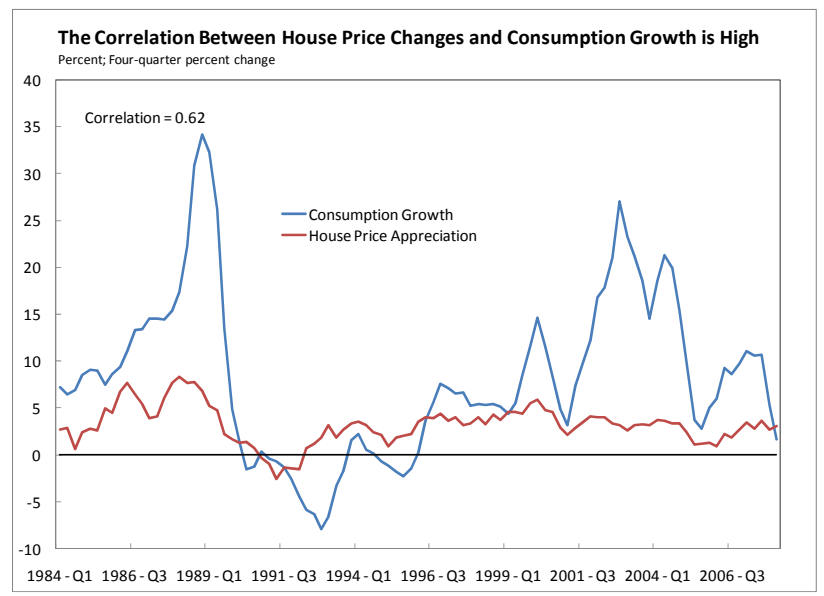

The correlation is robust to a variety of control variables. In a regression of consumption growth on various measures of wealth and a number of control variables, Bertaut (2002) estimates the marginal propensity to consume from nonfinancial wealth (primarily housing wealth) to be 8.8 percent in the United Kingdom. Other studies have come to similar conclusions.

Correlation, however, does not imply causality. Weak consumption growth, holding the stock of housing constant, will slow rent growth and lower house prices. ${ }^{19}$ On the other hand, housing wealth is a large proportion of household assets so declines in housing values imply significant reductions in household wealth, which lowers the level of consumption.

Whichever way the causality runs, a period of falling house prices is likely to be associated with very weak consumption growth. In addition, households fearing foreclosure are likely to reduce consumption, at least in the near term, to avoid foreclosure. Households currently in foreclosure are also unlikely to be able to access credit markets and may reduce consumption.

Therefore, if our forecast for prices and foreclosures is realized, we would expect the period of decline to be characterized by weak consumption growth. And, since

\footnotetext{
${ }^{19}$ The equation for house prices, equation 4 above, shows that the level of house prices is dependent on the ratio $\mathrm{U}_{\mathrm{h}} / \mathrm{U}_{\mathrm{c}}$. - the ratio of the marginal utility of housing to the marginal utility of consumption. As consumption growth slows, $\mathrm{U}_{\mathrm{c}}$ increases, lowering the level of house prices.
} 
consumption accounts for over 60 percent of GDP, the period of weak consumption growth is likely to also be associated with weak GDP growth.

\section{Residential Investment}

In addition to any impact on consumption, falling house prices are also likely to slow GDP growth through the contribution of residential investment. Residential investment currently accounts for around 4 percent of GDP in the United Kingdom. Figure 8 shows that this share increased over a percentage point between 2000 and 2007 . With the decline in construction activity, the share has begun to fall.

\section{Figure 8: Residential Investment as a Share of GDP}

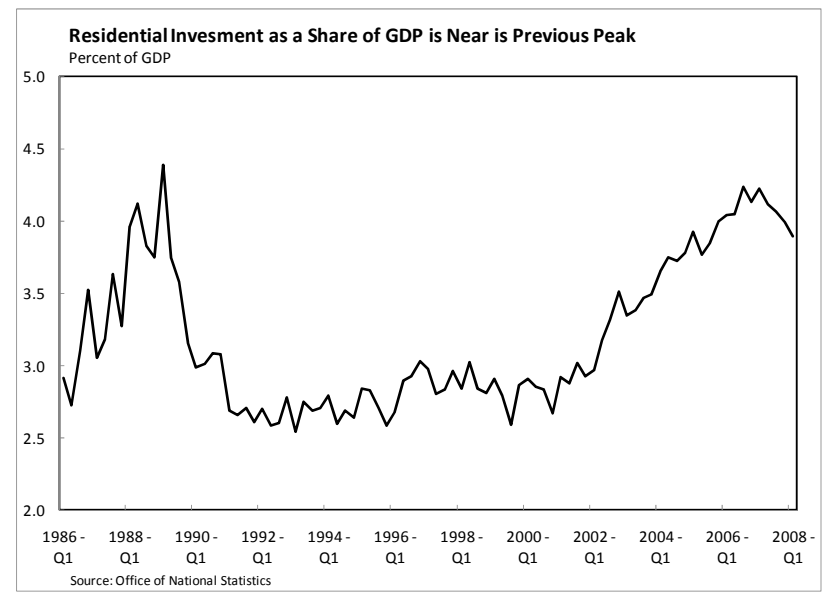

Figure 9 shows the contribution of residential investment to GDP growth over the same time period. The contribution shown is the four-quarter average of the quarterly contribution at an annual rate. The average removes some high frequency fluctuations in the contribution.

Since 2000, the contribution of residential investment has been generally positive, although at no time did it reach the peaks seen in the late 1980s. As house prices fall, construction is likely to fall and the contribution to GDP from residential investment is likely to be negative. 


\section{Figure 9: Contribution of Residential Investment to GDP Growth}

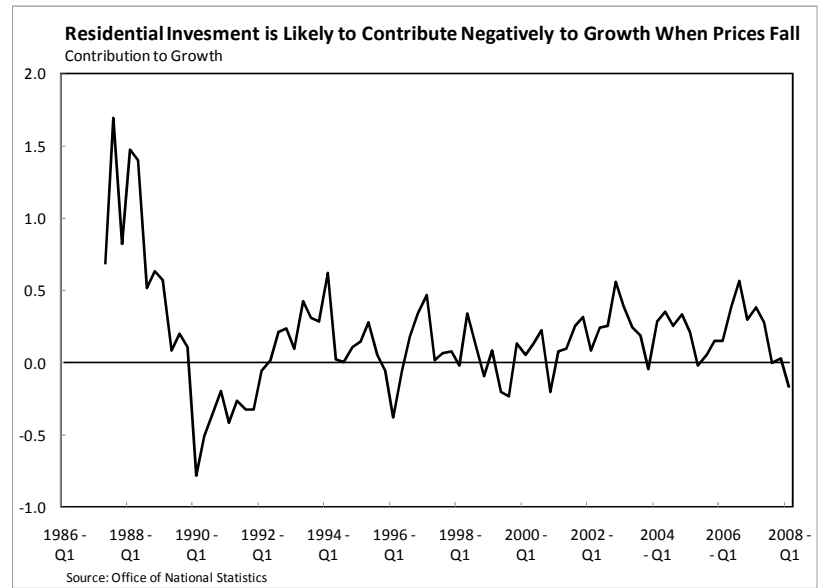

\section{Conclusion}

If the price-rent ratio is a reliable guide, house prices in the United Kingdom are likely to fall considerably in the near- to medium-term. House price appreciation is already negative and the market appears to be at a turning point. These price falls are likely to be associated with a very weak overall macroeconomic environment.

Of course, while the price-rent ratio is a good indication of value, it may not provide a reliable guide on the timing of turning points. If we had performed a similar analysis in 2005, we would have come to much the same conclusion, yet missed the peak by several years. Other indicators, however, do indeed indicate we have turned the corner. Housing fundamentals are weak, and without a turnabout in both these and mortgage-market turbulence, a significant fall in house prices seems unavoidable.

We also hope that this and similar papers (Davis et al 2008, Campbell et al 2006) will revive interest in using the price-rent ratio as an indicator of house valuation. Similar to price-earnings ratio for stocks, deviations in the price-rent ratio do not necessarily indicate valuation problems; however, unexplained deviations should be monitored and, as necessary, appropriate policy measures should be adopted. 


\section{Bibliography}

Ahearne, Alan, John Ammer, Brian M. Doyle, Linda S. Kole, Robert F. Martin. (2005)

"House Prices and Monetary Policy: A Cross-Country Study," International Finance Discussion Papers, 841.

Bertaut, Carol C. (2002) "Equity Prices, Household Wealth, and Consumption Growth in Foreign Industrial Countries: Wealth Effects in the 1990s," International Finance Discussion Papers, 724.

Bank of England. (2008) "Inflation Report," May

http://www.bankofengland.co.uk/publications/inflationreport/irlatest.htm

Calomiris, Charles W., Stanley D. Longhofer, and William Miles. (2008) "The

Foreclosure-House Price Nexus: Lessons for the 2007-2008 Housing Turmoil,” working paper, http://www.realestate.wichita.edu/draft/research/Academic_ForeclosureCrisis.asp

Cameron, David, John Muellbauer, and Anthony Murphy. (2006) "Was There a British House Price Bubble? Evidence from a Regional Panel," CEPR Discussion Paper, 5619.

John Y. Campbell, and João F. Cocco. (2005) "How Do House Prices Affect Consumption? Evidence from Micro Data,” NBER Working Paper No. 11534.

Campbell, Sean D., Morris A. Davis, Joshua Gallin, and Robert F. Martin. (2006) "A Trend and Variance Decomposition of the Rent-Price Ratio in Housing Markets," Finance and Economics Discussion Series, 2006-29.

Capozza, Dennis R., Patric H. Hendershott, Charlotte Mack, and Christopher Mayer. (2004), "Determinants of Real House Price Dynamics", Real Estate Economics, 32, 1-32.

Davis, Morris, Andreas Lehnert, and Robert F. Martin. (2008) "The Rent-Price Ratio for the Aggregate Stock of Owner-Occupied Housing," Review of Income and Wealth, 54, p 279-284.

Davis, Morris, and Robert F. Martin. (2008) "Housing, Home Production, and the Equity and Value Premium Puzzles," International Finance Discussion Papers, 931.

Gallin, Joshua. (2004) “The Long-Run Relationship Between House Prices and Rents," Finance and Economics Discussion Series, 2004-50.

Garino, Gaia, and Lucio Sarno. (2004), "Speculative Bubbles in UK House Prices: Some New Evidence", Southern Economic Journal, 70, 4, 777-95.

Himmelberg, Charles, Christopher Mayer, and Todd Sinai. (2005), “Assessing High House Prices: Bubbles, Fundamentals and Misperceptions", Journal of Economic Perspectives, 19, 4, 67-92.

IMF (2003), “An Analysis of House Prices in the United Kingdom”, United Kingdom: Selected Issues, IMF Country Report No. 03/47.

IMF (2005), “An Error Correction Model of House Prices”, United Kingdom: Selected Issues, IMF Country Report No. 05/81.

Mankiw, Greg, and David Weil, (1989), "The Baby Boom, the Baby Bust and the Housing Market", Regional Science and Urban Economics, 19, 325-46.

Martin, Robert F. (2005) "The Baby Boom: Predicatability in House Prices and Interest Rates,” International Finance Discussion Paper, 847. 
Poterba, James M. (1984), "Tax Subsidies to Owner-Occupied Housing: An Asset Market Approach,” Quarterly Journal of Economics, 99, 729-52.

OECD (2005), "Recent House Price Developments: The Role of Fundamentals", OECD Economic Outlook, 78, 193-234.

Roche, Maurice J. (2001), "The Rise in House Prices in Dublin: Fad or Just Fundamentals?", Economic Modelling, 18, 281-295.

Tsatsaronis, Kostas, and Haibin Zhu. (2004) "What Drives Housing Price Dynamics: Cross-Country Evidence," BIS Quarterly Review, March.

Wood, Robert. (2003), “The Information Content of Regional House Prices: Can They Be Used To Improve National House Price Forecasts?", Bank of England Quarterly Bulletin, Autumn, 304-14. 